\title{
Intellectual Capital Development Model of Muhammadiyah Higher Education in South Sulawesi
}

\author{
Edi Jusriadi ${ }^{1}$, Ida Bagus Wirawan ${ }^{2} \&$ Falih Suaedi ${ }^{2}$ \\ ${ }^{1}$ Management Department, Universitas Muhammadiyah Makassar, Sout Sulawesi, Indonesia \\ ${ }^{2}$ PSDM, Airlangga University, Surabaya, Indonesia \\ Correspondence: Edi Jusriadi, Management Department, Universitas Muhammadiyah Makassar, Sout Sulawesi, \\ Indonesia. E-mail: edi.jusriadi@unismuh.ac.id
}

Received: October 13, 2017 Accepted: November 27, 2017 Online Published: February 22, 2018

doi:10.5539/res.v10n1p117 URL: https://doi.org/10.5539/res.v10n1p117

\begin{abstract}
The dynamics of human resource development is characterized by the emergence of the issue of the workers diversity that occurs in an organization or institution. Diversity is defined as the difference in competence and individual attributes among lecturers within an institution. So with the issue, the objective of the research is Human Resource performance development based on Intellectual Capital. While the specific goals to be achieved to identify, analyze, and prove the contribution of intellectual capital development model as a process in supporting the performance of caturdharma lecturer of Muhammadiyah University (PTM) in South Sulawesi.

The research population is Lecturer of Muhammadiyah Universities in South Sulawesi with 158 lecturers selected by multistage sampling technique by using the method of descriptive statistic and Structural Equation Model (SEM).

The research found that the intellectual capital development model of Muhammadiyah university lecturer (PTM) in South Sulawesi was done through formal education method in the form of further study, non-formal education in the form of training, and education of Al-Islam and Kemuhammadiyahan values in the form of Baitul Arqam. The intellectual capital development model of lecturers through formal education, non-formal education, and Al-Islam and Kemuhammadiyahan values education has not directly contributed to improving the performance of the tridharma of higher education.
\end{abstract}

Keywords: Intellectual Capital, Human Resource Development, Muhammadiyah Higher Education, Performance Lecturer

\section{Introduction}

Along with the shift of society from industrialist society based on tangible assets resource to knowledge society which based on intangible assets resource increasingly make us realize how important role of human capital as asset or college capital, because college that able to compete in global level of course is college which has good human capital, so that improvement should lead to an increase in intellectual capital of human capital (Alwi, 2001: 58; Ulrich, 1997: 18).

In the quantity of Muhammadiyah Higher Education (PTM) in Sulawesi as much as 25 PTM or 14.12\% of 177 PTM in Indonesia, while in South Sulawesi alone there are 19 PTM or 9.74\%, so the existence of PTM in South Sulawesi much help government, private, and communities in the development and provision of human resources through education services and social activities. However, in terms of competitiveness and performance of university lecturers Muhammadiyah (PTM) in South Sulawesi is still low, based on data released QS-World, Webometrics, and BAN-PT, shows that from 20 best universities in Sulawesi only Muhammadiyah University of Makassar (PTM), which entered the top 20 universities in Sulawesi ranked 12 provinces, 257 National, 15801 in the world, with the accreditation value of institution B. (Qs-World, Webo, and BAN-PT, 2015), and even according to data released Kemeristekdikti from 11 best private universities in Indonesia there is no Muhammadiyah Universities (PTM) which entered the 11 best universities nationally. Muhammadiyah Universities (PTM) in South Sulawesi face the challenges of institutional governance quality, human resource quality issues, and academic processes.

Strategies to increase competitive advantage in human resource development (HRD) practices can be done through the development of intellectual capital (Alwi, 2001; Ulrich, 1997; Stewart, 1998). The development of intellectual capital in the views of Swanso and Holton, 2001 and Stoner, 2005 can be done through a learning process in the form of training and development. According to resource-based theory (RBT) of Wernerfelt, 1984 and Barney, 1991 that in an era of knowledge-based economy and information technology the demand for quality improvement, effectiveness and 
efficiency depends not only on the availability of physical capital and financial capital but depends on the role of human capital (Nothnagel , 2008). Thus Johanson et al., 1999, explains that technological competitiveness is only temporary, while sustained excellence depends on the development of intellectual capital the human capital and the ability of the organization to create added value (Lev, 2001; Sveiby, 2001; Hurwitz, et al. 2002).

The dynamics of human resource development is characterized by the emergence of the issue of the diversity of worke diversity) that occurs in an organization or institution. Diversity is defined as the difference in competence and individual attributes among lecturers within an institution. So with the issue of diversity then it takes the policy (policy) of the leadership to do human resources development.

According to system theory that human resource development (HRD) through training and development is leverage or as inputs that can improve performance, Sengge, 1990 (Swanson and Holton III, 2009). Explanation of system theory in kaitanya with research variables can be explained that the system input is lecturer. Then the process undertaken in developing intellectual capital, namely through the process of formal education, non-formal education, education value of Al-Islam and Kemuhammadiyahan. This process will result in fundamental competence of lecturers in the form of pedagogic competence, professional competence, social competence, and personality competence. So with the competence can be more easily in implementing Caturdharma. Furthermore, to evaluate the stages in system theory, there needs to be feedback (feedback) of the process stages carried out through lecturer workload report (BKD) every semester.

\section{Theoretical Review}

\subsection{Performance}

Herriegel, et al., (1989: 143) states that performance is a function of motivation and ability, which can be formulated as follows: Performance $=$ Ability x Motivation. While Blumberg and Pringle (1982: 565) stated that the performance of an employee is formed through the intraction between individual attributes, work efforts, and organizational support that can be formulated as follows: Performance $=$ Individual Attributes x Work Efforts x Organizational Support. Individual attributes, related to capacity to perform or personality. Work efforts, in relation to the efforts that a person undertakes in the work, such as the value / personal goals to meet the needs or to gain recognition. While organizational support, is an organizational support to individuals in work to meet the needs or values that are believed to individuals. The performance referred to in this study is the performance of lecturer Caturdharma (education and teaching, research and scientific publications, community service, and Al-Islam and Kemuhammadiyahan.

\subsection{Intellectual Capital (IC)}

Smedlund and Poyhonen, 2005; Rupidara, 2005 (in Solikhah, et.al., 2010), states that intellectual capital is the capability of individuals to create, transfer, and implement knowledge. Ulrich's opinion (1998), Burr and Girardi (2002: 77), which states that intellectual capital is the product of the intraction between competence, organizational commitment, and employment control of employees, so that if it is formulated into: Intellectual capital $=$ competence $\mathrm{x}$ commitment $\mathrm{x}$ job control. Organizations with high employee competencies without offsetting job commitments and controls will be in vain, while commitments without workplace competence and control are useless, so Ulrich says Burr and Girardi that the result of multiplication of the intellectual capital dimension will produce the ability (ability). Ability (ability) is referred to in this study is a competence that according to the Law Teachers and Lecturers. Law No. 14 Year 2005 article 10 paragraph 1 explains that lecturer competence includes: (1) pedagogic competence, (2) professional competence, (3) social competence and (4) personality competence.

\subsection{Intellectual Capital Lecturer Development}

Human resources (lecturers) are now recognized as human capital or intangible assets owned by the organization (PSK 19, revised 2010). Internally, the development of intellectual capital conducted by Muhammadiyah Universities (PTM), especially in South Sulawesi through the development of intellectual intelligence (IQ) by giving opportunities to lecturers for further study (formal education), development of emotional intelligence (EQ) through non-degree education, and the development of spiritual intelligence (SQ) through strengthening the values of Al-Islam and Kemuhammadiyahan implemented in the form of activities Darul Arqam and Baitul Arqam.

\subsection{Framework Think}

The foundation of research theory is resource based-theory (RBT) of processors developed by Wernerfelt, 1984 and Barney, 1991, which explains resources owned by both tangible assets and intangible assets resources. Intellectual capital in The Intangible Perspective Theory (Andriessen 2004), is considered an intangible resource of assets owned by human capital (Becker, 1964). Illustratively, the context of intellectual capital lecturer development model in relation to the theory used can be described as follows: 


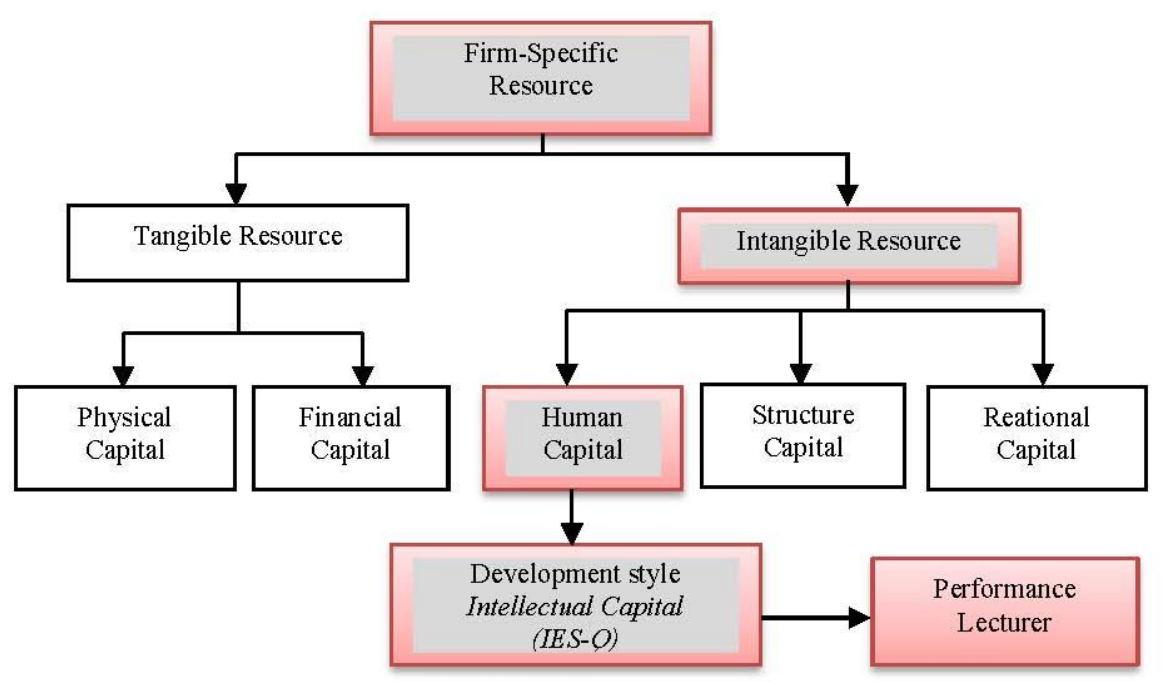

Figure 1. The Modification of the firm's resource scheme, Nothnagel, (2008).

\section{Method}

This research type is quantitative research with positivist approach, by using survey method through questionnaire and interview as instrument of data collecting. Furthermore data processing use descriptive statistic method and Sturctural Equation Model (SEM) analysis as a tool of analysis to test hypothesis with standard of appraisal level of significance $\alpha=$ 0.05 .

\section{Research Results}

\subsection{Results Descriptive Research Analysis}

Based on the results of interviews and analysis of the strategic plan (Renstra) of Muhammadiyah Higher Education in South Sulawesi, it was found that the effort of developing human resources or lecturers at Muhammadiyah Universities has been done through formal education process in the form of further studies, non-formal education in the form of training, and education value of Al-Islam and Kemuhammadiyahan in the form of activities Baitul Arqam.

\subsection{Inferential Statistics Analysis Results}

Based on the results of Inferential Statistic Analysis through the path coefficient test on the model of structural equation then the results of the study showed as follows:

Table 1. Hypthothesis Test Resut

\begin{tabular}{|c|c|c|c|c|c|c|}
\hline \multirow{2}{*}{ HIP } & \multirow{2}{*}{$\begin{array}{c}\text { Independent } \\
\text { Variable }\end{array}$} & \multirow{2}{*}{$\begin{array}{c}\text { Dependent } \\
\text { Variable }\end{array}$} & \multicolumn{4}{|c|}{ Direct Effect } \\
\hline & & & Standardize & $\mathbf{C R}$ & p-Value & Additional \\
\hline \multirow[t]{2}{*}{ H1 } & Formal education & Intellectual Capital & 0,253 & 2,360 & 0,018 & Significant \\
\hline & Non-formal & & & & & \\
\hline \multirow[t]{2}{*}{$\mathrm{H} 2$} & education & Intellectual Capital & 0,160 & 0,852 & 0,394 & Not Significant \\
\hline & Values & & & & & \\
\hline $\mathrm{H} 3$ & Education & Intellectual Capital & 0,568 & 3,454 & 0,000 & Significant \\
\hline
\end{tabular}

Indirect Effect 


\begin{tabular}{|c|c|c|c|c|}
\hline \multirow[b]{2}{*}{ Independent Variable } & Dependent & Intervening & \multirow[t]{2}{*}{ Standardize } & \multirow[b]{2}{*}{ Informatior } \\
\hline & Variable & Variable & & \\
\hline & Lecturer & \multirow[b]{2}{*}{ IC and PK } & \multirow[b]{2}{*}{0,156} & \\
\hline Non-formal education & Performance & & & Significant \\
\hline
\end{tabular}

Source: Attachment 4, research methodolgy, 2017

\section{Discussion}

Analysis of research model test results based on hypothesis can be explained as follows:

1) The contribution of formal education to intellectual capital

Path analysis results show that formal education contribute positively andsignificantly to intellectual capital. This is evidenced by the value of path coefficient of 0.253 and probability value of $0.018<0.05$. This finding is also supported by a critical ratio (CR) of 2.360 , which is greater than the required value of 1.65 . The results of this study indicate that the better formal education of a lecturer then intellectual capital will increase.

This finding is in accordance with the research results of Carrusso, 1999; Dharma (Sutrisno, 2011), which places intellectual intelligence (IQ) as a measure of success in work. Similarly, Kamidin, 2010 found that the dominant variable affecting work performance is the level of knowledge gained through formal education. But in contrast to the findings of Goleman (1995), found that the intelligence quotient (IQ) is only responsible for $20 \%$ of the success of one's life and opinions Riggio, (2000), who said that intelligence alone is not enough, because intelligence is only a tool. The facts in the study show that formal education as measured by indicators of education, science, justice and awards is still a problem in Muhammadiyah Universities (PTM). There are still $26.51 \%$ of lecturers of Muhammadiyah Universities (PTM) in South Sulawesi qualified as one star (S1), while in Law no. 142005 on Teachers and Lecturers affirms that the minimum academic qualification of a lecturer is strata Two (S2).

Problems academic qualification of lecturers not only has implications for the career of a lecturer in the form homeroom courses, counselors, testers, functional, certification, and the opportunity to obtain research grants and court of the society but also has implications for the relevant institutions accredited institutions and accrediting study programs. Specifically associated with a high rate still qualified lecturers percentage degree (S1) to challenge the leadership of Muhammadiyah Universities (PTM), so it takes a commitment of the leadership faculty oriented on quality (quality assurance).

2) Non-formal education contribution to intellectual capital.

Path analysis results show that non-formal education has no significant effect on intellectual capital. This is evidenced by the value of path coefficient of 0.160 and probability value of $0.394>0.05$. This finding is also supported by the critical ratio (CR) value of 0.852 , where this value is smaller than the required value, which is 1.65 . The result of the analysis means that non-formal education in the form of training, seminars, workshops and workshops that have been followed by lecturers has not significantly increased intellectual capital.

This finding is consistent research results Prisma Astuti (2009) found that non-formal education can not improve competence in supporting different from the results of research performance but Goleman (1995) who found that 80\% of success of one's life is determined by the non-intellectual intelligence. Similarly, the results Kamidin research, (2010) found that the skills have a positive and significant impact on employee performance.

a The facts in the study show that the non-formal education in intellectual capital is caused by several things, namely:

b Muhammadiyah Higher Education (PTM) has not implemented the needs assessment training in determining the training program.

c The results show that non-formal education constructed in the form of training is largely inappropriate to the needs of the participants. They even considered that the training was followed only as an ordinary or ritualistic routine because it did not fit operational tasks.

d A training system like a character and Applied Approach (AA) are constructed equally for all regions. While each region has a different culture as in Eastern Indonesia, people are more likely to like practical training than 
procedural ones, so Malcolm Knowles views individuals as learners and contributors to improve their own productivity. This means that individuals need to be given the freedom to construct their own training models such as what is needed based on experience, observation, and interaction with the environment (learning andragogy). Lecturer

e The quantity and quality (level of training) undertaken by the Muhammadiyah Higher Education (PTM) is still limited in terms of activity level, speakers, participants, and cooperation.

f Empirical data indicate that the level of lecturers' participation in training especially in compulsory training is still low, as $57.53 \%$ of lecturers have attended "pekerti" and $40 \%$ of lecturers applied Applied Approach (AA). While supporting training such as seminars, workshops, lecturer participation workshop of Muhammadiyah Higher Education (PTM) is more dominant as a participant.

3) Educational Contribution The value of Al-Islam and Kemuhammadiyahan.

The result of path analysis shows that Kemuhammadiyahan Al-Islam value education has significant effect on intellectual capital. This is evidenced by the path coefficient value of 0.568 and the probability value of $0.000<0.05$. This finding is also supported by the critical ratio (CR) of 3.454, which is greater than the required value of 1.65 . The results of this study means that the better the level of understanding and practice of Al-Islam values Kemuhammadiyahan then intellectual capital lecturers will also increase.

This finding is in accordance with Goleman's opinion, (1995); Mudali, (2002); Zohar \& Marshall, (2000) says that the key to achieving career and success in work is when the integration of three intelligences in human beings, namely: 1). intellectual intelligence (IQ), 2). emotional intelligence (EQ), and 3). spiritual intelligence (SQ). Similarly, Hoffmann, (2002), says that spiritual intelligence (SQ) has a broader dimension not only the question of aqidah, worship, and morals (religion) but also includes the meaning of life.

Facts in place of research indicate that education pattern of Al-Islam Kemuhammadiyahan value through Baitul Arqam activity for lecturer and employee and Darul Arqam for student have been done well. Value education is characteristic of Muhammadiyah Higher Education (PTM) and becomes intellectual capital for lecturers in performing their duties and functions, because a lecturer not only transfer of knowledge but a lecturer should also have good behavior that can be an example. In addition, the values of Al-Islam and Kemuhammadiyahan also implemented in the form of Al-Islam and Kemuhammadiyahan (AIK) curriculum through the course of it (AIK 1-8) which must be taught starting semester 1-8. Then in the 8th semester the students who will be in the thesis exams must pass the comprehensive examination of Al-Islam and Kemuhammadiyahan so that students and alumni are expected to have good intellectual competence, social competence and religious competence.

\section{4) Contribution of Non-Formal Education-Intellectual Capital-Work Behavior}

Path analysis results show that non-formal education has no significant effect on intellectual capital development. This result means that non-formal education in the form of training, seminars, workshops and workshops that have been followed by lecturers has not significantly increased intellectual capital.

The facts at the research site indicate that the non-formal education in intellectual capital is caused by training implementer and participant factor. From the aspect of implementing the training model applied from the curriculum, materials, and methods not according to the needs of the participants so that the training becomes regular routine or just simply abort the obligation so that for improvement on this aspect, it is necessary to apply the training needs assesment (TNA) in determining the training program. While from the side of the participants failure in achieving the objectives of training due to lack of awareness and weak supervision from the leadership, so that lecturers who participated in various training there is no reporting performance achievement.

Based on path analysis that non-formal education can contribute significantly in the development of intellectual capital to support the performance of tridharma when mediated by work behavior variables. This means that both training implementers and trainees should have good awareness or behavior in viewing the important role of non-formal education as an effort to improve performance. This finding is supported by the results of research Rahim Jusriadi \& Ruliaty (2017), who found that in order to improve the performance of a lecturer is not enough to only have intellectual capital but need to have good working behavior that can be formed from the process of education value of Al-Islam and Kemuhammadiyahan. 


\section{Research Findings}

The findings of this study complement the findings of Ulrich's research, (1998); Burr and Girardi, (2002). Where is the findings of Ulrich's research, (1998); Burr and Girardi, (2002) more on the formation of intellectual intelligence (IQ) and emotional intelligence (EQ) is more hard skill, but the results of this study found that to improve performance for a lecturer is not enough to have only intellectual intelligence (IQ) and intelligence emotional (EQ) is hard skill but need to be supported by the soft skill spiritual intelligence (SQ) which is manifested in the form of good working behavior. So that intellectual capital can be formed from the result of interaction between hard skill with soft skill that can be formulated in the form of IES-Q model as follows:

\section{Intellectual capital: Hard skill $x$ Soft skill $=$ Performance $($ Edi, 2017)}

\section{Conclusion}

The research found that Muhammadiyah University (PTM) in South Sulawesi in developing intellectual capital of lecturers is done through formal education method in the form of further study, non-formal education in the form of training, and education value of Al-Islam and Kemuhammadiyahan. The intellectual capital development model of lecturers through formal education, non-formal education, and Al-Islam and Kemuhammadiyahan values education has not directly contributed to improving the performance of the Tridharma of higher education.

It is interesting from the study's findings that non-formal education can contribute significantly when in mediation of work behavior variables formed from the process of educating the value of Al-Islam and Kemuhammadiyahan, this means that the better the process of formal education, non-formal education, and value education Al-Islam and Kemuhammadiyahan then the work behavior of lecturers is also increasing so that affect the performance of Caturdharma lecturer Muhammadiyah University (PTM) in South Sulawesi.

\section{Acknowledgments}

This research can be completed because of support from promoter, co-promoter, graduate school of Unair Surabaya, Kopertis Region IX Sulawesi, head and lecturer of Muhammadiyah university in South Sulawesi.

This research is funded by the Directorate of Research and Community Service-Kemeristekdikti 2017, which further followed by workshop and Clinic improving the quality of research results of research programs to improve the research capacity of Makassar region.

\section{References}

Alwi, S. (2001). Management Human Resource: Strategy competitive Advantage (1st ed.). Yogkarta: BPFE.

Andriessen, D. (2004). Making Sense of Intellectual Capital Designing a Method for tha Valuation of Intangibles, USA: Elsevier, Inc.

Barney, J. (1991). "Firm Resources and Sustained Competitive Advantage”, Journal of Management, 17(1). https://doi.org/10.1177/014920639101700108

Becker, G. S. (1964). Human Capital: A Theoretical \& Empirical Analysis. Edition Columbia University Press. New York.

Blumberg, M. dan C. D. P. (1982). "The Missing Opportunity inOrganizational Research: Some Implication For a Theory of Work Motivation". Academy of Management Review, 7, 563-569

Burr, R., \& Antonia G. (2002). Intellectual Capital: More Than The Interaction of Competence x Commitment. Australian Journal of Management. Sydney., 77-78. https://doi.org/10.1177/031289620202701S09

Carruso, D. R. (1999). Applying The Ability Models Of Emotional Intelligence To World Of Work. http://cjwolfe.com/article.doc. Diakses 15 Januari 2016.

Departemen, A. R. I. (2005), Al-Qur'an dan Terjemahan, Jakarta: PT Syamil Cipta Media

Goleman, D. (1995). Emotional Intelligence: Why It Can Matter More Than IQ For Character, Health and Lifelong Achievement. Bantam Book. New York.

Herriegel, D., Slocum, J., \& Woodman, R. W. (1989). Organizational Behavior. Singapore: Fifth Edition. Herper \& Row Pulisher

Hoffman, E. (2002). Psychological Testing At Work, McGraw Hill, New York.

Hurwitz, J., S. Lines, B. Montgomery, \& Schmidt, dan J. (2002). "The Linkage Between Management Practice, Intangible Performance and Stock Returns". Journal of Intellectual Capital, 3(1), 51-61.

https://doi.org/10.1108/14691930210412845 
Financial Accounting Standard Board (FASB), (1980). Qualitative Characteristics of Accounting Information, FASB, SFAC No.2.

Ikatan A. I. (2012a). PSAK No. 19 (revisi 2010) tentang Aset Tak berwujud. Jakarta: IAI

Johanson, U., Martenson., M. \& Skoog, dan M. (1999). of Coference. "Measuring and Managing Intangibles, Eleven Swedish Qualitative Exploratory Case Studis". Artikel dipresentasikan pada Accounting for Intangible and the Virtual Organization, Februari , di Brussels.

Kamidin, M. (2010). "Pengaruh Kompetensi Terhadap Prestasi Kerja Pegawai Sekretariat Daerah Kabupaten Bantaeng”. Jurnal Economic Resources, ISSN. 0852-1158, 11(30).

Lev, B. (2001). Intangible: Management, Measurement, and Reporting. Washington: The Brooking Institution.

Mudali, K. (2002). Quote: How High Is Your Spritual Intelligence?. Retrieved From: http://ww.eng.usf.edu/qopalakr/articles/spritual.html. Diakses 15 Januari 2016.

Nothnagel, K. (2008). Empirical Research Within Resource Based Theory: A Meta Analysis of the Central Propositions. Germany: Gabler.

Pernyataan Standar Akuntansi Keuangan (PSAK) No.19 tentang Aktiva Tak Berwujud. http://pajak.go.id/perpustakaan/indeks.php?.p=show_detail\&id=4813, Diakses tanggal 18 Desember 2016

Rahman, R., Jusriadi, E., \& Ruliaty. (2017). Role of Intellectual Capital and Work Behavior in Supporting Lecturer's Performance. Review of European, 9(3), 117-125. https://doi.org/10.5539/res.v9n3p117

Riggio, R, E. (2000). Introduction To Industrial/Organizational Psychology, Third Edition, Prentice Hall, New Jersey.

Solikhah, B., et al. (2010). Implikasi Intellectual Capital terhadap Financial Performance, Growth and Market Value: Studi Empiris dengan Pendekatan Simlistic Specifiestion. Simposium Nasional Akuntansi (SNA) XIII. Pontianak.

Stewart, T. A. (1998). Intellectual Capital: Kekayaan Baru Organisasi, Alih Bahasa: Reza Gunawan, Jakarta:PT Alex Media Komputindo.

Stoner, J. (2005). Manajemen. Jakarta: Prenhalindo

Sutrisno, Edi. (2011). Manajemen Sumber Daya Manusia. Edisi Pertama, Jakarta: Kencana Prenada Media Group.

Swanson, R. A., Elwood, F., \& Holton, III. (2001). Foundations of Human Resource Development. San Francisco: Berrett-Koehler Publisher, Inc (BK).

Swanson, R. A., \& Elwood, F., \& Holton, III. (2009). Foundations of Human Resource Development. Second edition, San Francisco: Berrett-Koehler Publisher, Inc (BK).

Sveiby, K. E. (2001). “A Knowledge-Based-Theory of the Firm to Guide in Startegy Formulation”. Journal of Intellectual Capital, 2(4), 344-358. https://doi.org/10.1108/14691930110409651

Ulrich, D. (1997). Human Resouce Champions. Boston: Harvard Business School Press. Wright.

Ulrich, D. (1998). Intellectual Capital = Competence x Commitment. Sloan Management Review, 39, 15-26.

Undang-Undang Nomor 14 Tahun 2005 Tentang Guru dan Dosen, Jakarta: Diknas

Undang-Undang Nomor 20 Tahun 2003 Tentang Sistem Pendidikan Nasional, Jakarta: Diknas

Wernerfelt, Birger. (1984). A Resource Based View of the Firm. Strategic Management Journal, 5, 171-180. https://doi.org/10.1002/smj.4250050207

Zohar, D., \& Marshall, I. (2000). SQ (Spritual Intelligence): The Ultimate Intelligence, Bandung: Mizam Media Utama.

\section{Copyrights}

Copyright for this article is retained by the author(s), with first publication rights granted to the journal.

This is an open-access article distributed under the terms and conditions of the Creative Commons Attribution license (http://creativecommons.org/licenses/by/4.0/). 